Canadian University Music Review

Canadian University Music Review

Revue de musique des universités canadiennes

\title{
First Nations Popular Music in Canada: Musical Meaning and the Politics of Identity
}

\section{Christopher Scales}

Volume 19, numéro 2, 1999

Canadian Perspectives in Ethnomusicology

Perspectives canadiennes en ethnomusicologie

URI : https://id.erudit.org/iderudit/1014450ar

DOI : https://doi.org/10.7202/1014450ar

Aller au sommaire du numéro

Éditeur(s)

Canadian University Music Society / Société de musique des universités canadiennes

\section{ISSN}

0710-0353 (imprimé)

2291-2436 (numérique)

Découvrir la revue

Citer cet article

Scales, C. (1999). First Nations Popular Music in Canada: Musical Meaning and the Politics of Identity. Canadian University Music Review / Revue de musique des universités canadiennes, 19(2), 94-101. https://doi.org/10.7202/1014450ar
Résumé de l'article

The musics of First Nations popular musicians "Wapistan" Lawrence Martin and the Innu group Kashtin are examined as polysemic signs whose meaning is mediated both socially and politically in the ongoing construction of First Nations socio-cultural identity. Musical meanings on individual, local, national, and international levels are dependent on the socio-political positioning of both the performers and the audience. Because socio-political positions are themselves fluid, political meanings are, as well, in constant flux. As a polysemic sign, First Nations popular music is a locus for these various meanings and a site for the construction and deconstruction of political discourse.
All Rights Reserved @ Canadian University Music Society / Société de musique des universités canadiennes, 1999
Ce document est protégé par la loi sur le droit d'auteur. L’utilisation des services d'Érudit (y compris la reproduction) est assujettie à sa politique d'utilisation que vous pouvez consulter en ligne.

https://apropos.erudit.org/fr/usagers/politique-dutilisation/ 


\title{
FIRST NATIONS POPULAR MUSIC IN CANADA: MUSICAL MEANING AND THE POLITICS OF IDENTITY
}

\author{
Christopher Scales
}

In the last decade, the output of First Nations popular music has steadily increased. Paving the way for the more recent commercial successes of artists such as Susan Aglukark, Lawrence Martin, the Seventh Fire, and Don Ross, to name only a few, is the unprecedented, late 1980s success of the Innu group Kashtin, a duo consisting of Florent Vollant and Claude McKenzie, both Innu (Montagnais) from Northern Quebec. ${ }^{1}$ A decade later, unique forms of syncretic popular music are quietly making headway within mainstream Canadian culture. As this music has received attention nationally through the mass media, it has become an important medium for the creation, negotiation, and maintenance of Canadian First Peoples' social and cultural identity. As Stokes, among others, has articulated, music is socially meaningful in that it provides means by which people recognize social and cultural identities and the boundaries that separate them. ${ }^{2}$ As such, First Nations popular music functions as an emblem of symbolic differentiation between Canadian natives and non-natives. Musical meanings, however, on individual and social levels, are in a constant state of negotiation and mediation and are dependent on one's sociopolitical positioning.

In this essay, I discuss the music of Lawrence Martin and the musical group Kashtin and examine how these artists and their music function in the construction of a Canadian First Nations cultural identity. ${ }^{3}$ The shifting, polysemic nature of this identity is highlighted in examining how concurrent political events in other social spheres function in the negotiation of musical meaning.

I would first like to discuss Lawrence Martin, a mixed-blood Cree musician from the small Northern Ontario town of Moose River. He has released two albums to date: Wapistan Is Lawrence Martin (Sioux Lookout: First Nations Music, 1993) and The Message (Sioux Lookout: First Nations Music, 1995).

Martin's music is a stylistic blend of modern country-rock and the Irish and French jigs and reels he learned in his youth. He sings in a mix of Cree and

1 Innu is the self-identification of the group; Montagnais is the name given to the Innu people by Europeans since the sixteenth century.

2Martin Stokes, Ethnicity, Identity and Music: The Musical Construction of Space (Providence, R.I.: Berg, 1994), 5.

3Despite their success, as of 1999, Martin is no longer active in the music business and Kashtin has temporarily broken up while McKenzie and Vollant pursue solo careers. 
English. His English-language songs are more overtly political, dealing with many of the social issues faced by First Nations peoples: residential school experiences, cultural alienation, and the loss of religion and language. Conversely, his Cree-language songs more typically deal with themes of cultural pride and rejuvenation. Martin's music includes a number of chants written in a traditional Cree musical style. In recasting a traditional sounding chant in a modern country-rock style, a song such as "Elders" functions as a symbolic representation of the modern Native socio-cultural circumstance. During an interview between Martin and myself, he spoke about the inclusion of Native chanting in his music:

I use the chant to challenge society-and to inspire the young Native people to feel good about their culture. It's cool we can sing our music anywhere; we don't have to just hide in the bush and do our powwow ceremonies. Plus I want society to also understand and accept the music as part of the Canadian mosaic. ${ }^{4}$

Martin's music provides a place where some of the conflicting aspects of modern Native identity are worked out. In his own case, his music is a reflection of his mixed Cree and Irish heritage. He commented on this, saying:

The area I come from, the Hudson Bay area-a lot of the Irish and the Scottish and French came up that way and they brought their music with them. The Cree people adapted to this music fairly quickly. And the elders used to tell me that the Crees would be playing with their hand drums along with the French or the Irish people as they were playing their fiddles. And over the years, the fiddle has been really popular with the Cree people in the James Bay area. And so today, when you go up there, you still hear a lot of these jigs and reels. ${ }^{5}$

The fiddle tradition among James Bay Cree may date as far back as the seventeenth century, a time when the Hudson's Bay Company trading posts were first established in the area. ${ }^{6}$ Thus, while Martin recognizes the nonNative origins of the music, fiddling has, nonetheless, become an important part of the Cree and Métis musical heritages.

Martin's music also serves to contest stereotypical images of Native culture. The misrepresentation of Native culture in the mass media and the appropriation of First Nations mythology and iconography in Western literature and visual art has recently drawn the attention of a number of scholars, as well as First Nations writers and artists. ${ }^{7}$ Lawrence Martin is very aware of the problem of Native identity in the public mind. He has said:

4Lawrence Martin, interview by the author, 25 September 1995, Vancouver.

5 Ibid.

6Richard J. Preston, "Transformations musicales et culturelles chez les Cris de l'Est," trans. Nicole Beaudry and Evelyne Cossette, Recherches Amerindiennes au Québec 15, no. 4 (1985): 23.

7For example, see Valda Blundell, New Directions in the Anthropological Study of Art (Ottawa: Carleton University Press, 1992); Ward Churchill, "Fantasies of the Master Race: Categories of Stereotyping of American Indians in Film," in Fantasies of the Master Race: Literature, Cinema and 
I think more and more now it's not just the cultural stuff we need to focus on. We've got a lot of people who think Indians are still stuck in a particular era and they're still running around with loincloths and headdresses, and riding horseback. But that's not the Indian of today. The Indian of today could just be sitting in a hotel room doing interviews or fighting out court battles or running a business. ${ }^{8}$

An important function of Martin's music is its ability to reclaim the power to define Native cultural identity. Adaptation of Euro-North American cultural forms does not diminish Native identity. Like all cultures, First Nations people and culture are in a constant state of growth and adaptation. Native pop music is both a reflection and an active contributor to this process.

Cultural identities can be understood in terms of the construction, maintenance, and negotiation of boundaries. ${ }^{9}$ These boundaries exist only in a context of opposition and relativity. Often, these boundaries are constructed and defended through the use of concepts such as "authenticity." 10 The issue of authenticity is particularly relevant to Canadian Native pop music as it has been the subject of a vigorous debate which has been played out in the Canadian popular press in the past number of years. Both the Native community and the larger Canadian music community have struggled with the definition of "authentic" Native music.

In a national newspaper article on the topic, Cree folksinger Buffy SainteMarie is quoted as stating: "[Native popular music is] not just somebody with a $\tan$ and a guitar ... [it] is not just a racial category. There are distinctive elements to the genre like the use of drums and an insistent beat."11 SainteMarie seems to be defining the parameters of the music through an inventory of stylistic features. However, later in the same article, Shingoose, an Ojibway singer from Manitoba, offers:

My influences were the Beatles and the Stones, like everybody else ... When you start to get more responsible and you see your people suffering, there is an awakening. What makes me different, if I am different? It leads to a mingling of traditional and contemporary. It's conceptual rather than sound. ${ }^{12}$

the Colonization of American Indians, ed. M. Annette James (Monroe: Common Courage Press, 1992); James A. Clifton, ed., The Invented Indian: Cultural Fictions and Government Policies (New Brunswick, N.J.: Transaction Publishers, 1990); Daniel Francis, The Imaginary Indian: The Image of the Indian in Canadian Culture (Vancouver: Arsenal Pulp Press, 1992); Rick Hill, "In Our Own Image: Stereotyped Images of Indians Lead to New Native Artform," Muse (1989): 32-37; Ruth B. Phillips, "What is 'Huron Art'? Native American Art and the New Art History," The Canadian Journal of Native Studies 14, nos. 1/2 (1989): 15-31. Gerald McMaster and Carl Beam are two First Nations artists that employ and treat stereotyped Native images ironically in their works.

8Lawrence Martin, interview by the author, 25 September 1995, Vancouver.

9Frederick Barth, Ethnic Groups and Boundaries: The Social Organization of Cultural Difference (London: George Allen and Unwin, 1969).

10 Stokes, Ethnic Identity and Music.

11 In Kate Taylor, "Native Music is a Hot Ticket These Days, a Fact Recognized with a Brand New Juno Award," Globe and Mail (Toronto), 20 March 1993, C1, C2.

12Ibid. 
Shingoose seems to be suggesting that it is process and approach which define the genre. The struggle over definitions and interpretations is significant because trying to define the authentic through an identifiable "sound" can be a political strategy. Because the music functions as a locus for self-definition, the issue of who controls the definitions and what criteria are valued and endorsed as authentic become of paramount importance.

On the one hand, the creation of a category like "Native music" puts a name to the music, defining it as separate and unique from the rest of the Canadian cultural mosaic. In this sense, the category can have a positive effect for those whose cultural politics assert difference between Native culture and Canadian culture as a whole. Lawrence Martin, on the other hand, has commented that he is not completely comfortable with this distinction as it can result in being labelled out of the "mainstream:"

I don't know if Native popular music needs to be categorized. I went into a record store the other day and looked for my new album in the main section, but it wasn't there. It was tucked away in a corner where they have a section for Native artists. But I'd like to be part of the mainstream instead of just being categorized Native. I mean do you have a Black section, or a White section. I don't think you can classify music by race. ${ }^{13}$

Martin's comments allude to the complex nature of Native identity within Canadian culture, where Natives wish to be recognized as both distinct but equal in the eyes of both the Canadian government and the general public.

The argument over authenticity in Native music came to a head with the creation of a new "Aboriginal music" category in 1994 by the Canadian Academy of Recording Arts and Sciences (CARAS). CARAS is responsible for the annual presentation of the Juno awards, Canada's national music awards (the equivalent of the American music industry's Grammy awards). A controversy over the presentation of the 1994 Juno award for Aboriginal music came about because one of the four nominees for the award, Sazacha Red Sky, was not of Native descent. Furthermore, she won the nomination for "The Prayer Song," a song which she learned from the British Columbian Native leader and Hollywood actor Chief Dan George.

Questions of authenticity became mixed with accusations of appropriation. Dan George's son, Leonard, attempted to have the nomination withdrawn and accused Ms. Red Sky of "violating a trust as [she] had no right to record his family's prayer." 14 Lawrence Martin, who eventually won the award, stated:

Someone from a different culture taking a song that belongs to a particular clan isn't right. There's protocols that they have to watch out for. You ask for the song, you give tobacco ... You give an offering to get that song given to you, giving you the right to use it. ${ }^{15}$

13Lawrence Martin, interview by the author, 25 September 1995, Vancouver.

14Larry McCallum, "Just Another Greedy White Explorer," Western Report, 11 April 1994, 42.

15Lawrence Martin, interview by the author, 25 September 1995, Vancouver. 
The preceding discussion serves to illustrate how contextualization is pivotal in the mediation of political meaning. The boundaries dividing Native and non-Native popular music are becoming increasingly blurred. However, while these boundaries are stylistically flexible, they are passionately defended. The concept of "authenticity" is used as a powerful "discursive trope" 16 by both musical producers and consumers. What is interesting is not so much what defines "authentic" Aboriginal music, but how the concept of authenticity is used in the construction and maintenance of social and cultural identity. Mediation of the authentic takes place within the historical and contemporary complex of power relations. Given the colonial history of Canada with respect to Aboriginal peoples, the appropriation of Native musical styles by nonNative musicians becomes a highly politically charged activity. However, at the same time, Aboriginal musicians freely adapt North American and AfroAmerican popular musical forms, feeling that these forms are a valid part of their cultural heritage.

While Native musicians are hesitant to define Native pop music by bloodline alone, its definition lies as well outside any simple stylistic considerations. This ambivalence points, perhaps, to the idea that the shifting nature of the definition of Native pop music is tied to its political functioning in the Native community and in the larger multicultural Canadian community.

It is often difficult for First Nations popular music to avoid having political associations, even when First Nations musicians present themselves as self-consciously apolitical. The musical group Kashtin is an example of this. While their music is a blend of both folk and pop styles, they sing virtually all of their music in their native tongue of Montagnais, a language spoken by only approximately 10,000 people in eastern Quebec and northern Labrador. ${ }^{17}$

Kashtin's music is politicized through their very use of the Montagnais language which acts as a sign, indexing the concept of "difference" between Native pop music and non-Native pop music. I believe that for many First Nations listeners, this textual difference comes to represent cultural difference. Kashtin is very careful in speaking about the political nature of their music and have gone to great lengths to distance themselves from any direct political statements. In an interview from 1990, Vollant stated:

... we don't try to make political statements. We want to reach people through our music, that's what we came out of the reserves to do. If people put as much effort into defending Native rights as we do communicating through our music, everything should be okay. ${ }^{18}$

16Stokes, Ethnicity, Identity and Music, 6.

17Alan D. McMillan, Native Peoples of Canada: An Anthropological Overview (Vancouver: Douglas and McIntire, 1988).

18Stephen Godfrey, "Toronto Strikes a Chord," Globe and Mail (Toronto), 13 October 1990, C1, C14. 
Elsewhere, however, Vollant has admitted:

It's almost impossible to be a native performer and not be political. We prefer to do it by showing native culture in a positive way. We aren't interested in making aggressive, confrontational music because that's not the spirit of what we do. ${ }^{19}$

Most obviously, the presence of the Montagnais language in Kashtin's songs is a source of pride and an expression of power for those who speak and understand the language. When Kashtin sing in Montagnais, it affirms the fact that they, as Innu, can function within spheres which have been traditionally controlled by the dominant Canadian culture, i.e., the sphere of the Canadian popular music industry, while remaining true to their cultural heritage. However, Kashtin is a source of pride for the larger Native community as well, something of which they are well aware. Vollant has said that the pride generated among Native peoples is one of the most satisfying aspects of their success. He has stated: "People of all Native nations are proud of what we've done. They support us completely."20

One of the effects of this symbolic differentiation between Native and non-Native culture is its power to group the various First Nations as a single cultural group, united by "shared feelings, history, and collective identity that marks the social group as a distinct entity bound by common will."21 However, this type of representation also has the negative effect of minimizing cultural differences among different First Nations groups in the eyes of the general public. This was exemplified most clearly when the music of Kashtin was banned by a number of radio stations in Quebec in the summer of 1990.

That summer, a tense confrontation developed between people of the Mohawk Nation and the Quebec government. In an effort to block the expansion of a golf course onto land to which they had claimed Aboriginal title, the Mohawks erected a barricade on a dirt road leading to the proposed expansion site. This developed into a lengthy armed stand-off between the Mohawks and the Quebec police.22 This political situation brought about the boycott of Kashtin's music by a number of Montreal radio stations during the time of the crisis. Vollant's comments in a Toronto newspaper, on both the stand-off and the boycott, were guarded and ambivalent. He stated, "We are in solidarity with

19Lenny Stoute, “Innu Rockers Let Their Music Do Their Politicking,” Toronto Star (Toronto), 18 January $1992, \mathrm{~K} 1$.

20 Paul Delean, "Kashtin Cashes in on Novelty Craze," Gazette (Montreal), 19 February 1990, B13.

21 Louis Meintjes, "Paul Simon's Graceland, South Africa, and the Mediation of Musical Meaning," Ethnomusicology 34, no.1 (1990): 63.

22For a detailed discussion of the crisis, see James S. Frideres, Aboriginal Peoples in Canada: Contemporary Conflicts (Scarborough, Ont.: Prentice Hall, 1998), 334-57. For an analysis of the events relating to Kashtin, see Line Grenier and Val Morrison, "Quebec Sings 'E Uassuian': The Coming of Age of a Local Music Industry," in Popular Music: Style and Indentity: International Association for the Study of Popular Music Seventh International Conference on Popular Music Studies, ed. Will Straw, Stacey Johnson, Rebecca Sullivan, and Paul Friedlander (Montreal: Centre for Research on Canadian Cultural Industries and Institutions, 1995), 127-30. 
the Mohawks, but violence makes people fearful, and we do not agree with taking up arms in violence." 23 However, Vollant was also careful to point out the historic cultural differences between the Montagnais and the Mohawks, stating:

The Montagnais are nomadic people who are known for being peace loving ... The Mohawks on the other hand, throughout history have been very warlike, and always on the front line of national issues. Everyone must understand that we are different, and we have the right to our differences. ${ }^{24}$

Kashtin's shifting position on the representation of Native identity is typical of how the meaning of Native popular music is constructed and mediated by socio-political context. It comes as no surprise that various social actors affix different individual, social, and political meanings to music. However, the comments of Kashtin and Lawrence Martin exemplify the dynamic nature of meaning production and how different symbolic meanings are highlighted, suppressed, and manipulated by individual musicians as they react and interact with mass mediated responses to the music and shifting state of political relations between First Nations groups and Canadian government institutions.

This essay has focused on two general themes: (1) the potential of massmediated music in the public construction of First Nations identity, and (2) the role played by the discourses of "authenticity" and "appropriation" in the negotiation of this identity. Rather than mapping the content of the category of "Native popular music," I have instead tried to explore some of the ways in which the category is articulated relative to different socio-political agendas at different times, and I have presented some of the often contradictory meanings that result.

The controversy surrounding the Aboriginal Juno award linked Native pop music to the ideology of cultural (perhaps even racial) essentialism. Red Sky's music was not "aboriginal" because she was not Aboriginal. Despite this, Lawrence Martin maintained that First Nations music should not be categorized by race. Similarly, Kashtin's music, in the context of the political unrest surrounding the Oka crisis, became linked to the discourse of pan-Indianism at a time when the members of Kashtin were trying to distance themselves from that position. ${ }^{25}$ I want to be clear that I am in no way suggesting duplicity in the actions or words of these musicians. Quite the contrary, mass-mediated popular music is an ideal tool for construction and negotiation of identity precisely because its polysemic nature allows for an expression of the complex and polyvalent nature of identity.

Lawrence Martin considers himself both a Cree and a Canadian, as a Native musician and a musician who happens to be a Native, drawing on elements of his own particular socio-cultural experience in the creation of his music.

23 Godfrey, "Tornado Strikes a Chord."

24 Ibid.

25Lawrence Martin, interview by the author, 25 September 1995, Vancouver. 
Similarly, the members of Kashtin justifiably assert that their music is an expression of both pan-Indian sentiment and their unique experience as Innu (Montagnais).

The larger theoretical point is that musical meaning cannot simply be read off the surface of the musical text. Recent work by Karl Neuenfeldt ${ }^{26}$ and Elaine Keillor $^{27}$ has provided cogent and insightful analyses of the lyrics of aboriginal pop musicians and their role in identity construction. However, textual analyses tend to imply a simplified, one-way, sender-receiver model of musical communication in which mediation stops at the moment of audience reception (the message is unproblematically received and interpreted). This paper has tried to demonstrate that mass-mediated musics continue to generate and/or highlight new meanings through their re-articulation into other socio-political projects such as national music awards celebrating multiculturalism or violent political protest.

\section{Abstract}

The musics of First Nations popular musicians "Wapistan" Lawrence Martin and the Innu group Kashtin are examined as polysemic signs whose meaning is mediated both socially and politically in the ongoing construction of First Nations socio-cultural identity. Musical meanings on individual, local, national, and international levels are dependent on the socio-political positioning of both the performers and the audience. Because socio-political positions are themselves fluid, political meanings are, as well, in constant flux. As a polysemic sign, First Nations popular music is a locus for these various meanings and a site for the construction and deconstruction of political discourse.

26Karl Neuenfeldt, "To Sing a Song of Otherness: Anthros, Ethno-pop and the Mediation of Public Problems," Canadian Ethnic Studies 23, no. 3 (1991): 92-118; "First Nations and Métis Songs as Identity Narratives," International Journal of Canadian Studies 12 (1995): 201-20; "Songs of Survival: Ethno-pop Music as Ethnographic Indigenous Media," Australian-Canadian Studies 14, nos. 1/2 (1996): 15-31.

27Elaine Keillor, "The Emergence of Postcolonial Musical Expressions of Aboriginal Peoples within Canada," Cultural Studies 9, no. 1 (1995): 106-24. 